\title{
ARTICLE
}

\section{Lack of $\beta$-catenin in early life induces abnormal glucose homeostasis in mice}

\author{
S. Dabernat $\cdot$ P. Secrest $\cdot$ E. Peuchant $\cdot$ \\ F. Moreau-Gaudry $\cdot$ P. Dubus $\cdot$ N. Sarvetnick
}

Received: 16 January 2009 /Accepted: 15 April 2009/Published online: 10 June 2009

(C) Springer-Verlag 2009

\begin{abstract}
Aims/hypothesis Wingless and iNT-1 (WNT) pathway members are critical for pancreatic development and exocrine tissue formation. Recently, much attention has focused on delineating the roles of $\beta$-catenin in pancreatic organogenesis. However, little is known about the involvement of $\beta$-catenin in the endocrine or exocrine function of the mature pancreas. We report for the first time the impact of $\beta$-catenin deletion in the pancreatic beta cells.

Methods We targeted the deletion of the $\beta$-catenin gene in pancreatic beta cells by crossing a floxed $\beta$-catenin mouse strain with a RIP-Cre mouse strain.

Results Surprisingly, the majority of the mutant mice died shortly after birth and had deregulated glucose and insulin levels. The newborn mutant pancreases demonstrated increased insulin content, reflecting a defect in insulin release confirmed in vitro. Moreover, there was a reduction in total endocrine tissue at birth, while cellularity in islets was greater, suggesting that lack of $\beta$-catenin affects beta
\end{abstract}

Electronic supplementary material The online version of this article (doi:10.1007/s00125-009-1411-y) contains supplementary material, which is available to authorised users.

S. Dabernat $\cdot$ P. Secrest $\cdot$ N. Sarvetnick

Department of Immunology, The Scripps Research Institute,

La Jolla, CA, USA

S. Dabernat $(\bowtie) \cdot$ E. Peuchant $\cdot$ F. Moreau-Gaudry $\cdot$ P. Dubus

Université Victor Segalen Bordeaux 2,

146, rue Léo Saignat,

33076 Bordeaux Cedex, France

e-mail: sandrine.dabernat@u-bordeaux2.fr

S. Dabernat $\cdot$ E. Peuchant $\cdot$ F. Moreau-Gaudry

INSERM, U876,

33076 Bordeaux Cedex, France cell size. Some newborns survived $\beta$-catenin deletion and showed a milder phenotype during adulthood.

Conclusions/interpretation The deletion of $\beta$-catenin in the maturing beta cells negatively impacts on islet morphology and function. This work reveals that lack of $\beta$-catenin in early life is related to severe deregulation of glucose homeostasis.

Keywords Beta-catenin - Beta cell · Insulin secretion · Pancreas $\cdot$ WNT

$\begin{array}{ll}\text { Abbreviations } \\ \text { LRP5 } & \begin{array}{l}\text { Low-density lipoprotein receptor-related } \\ \text { protein 5 }\end{array} \\ \text { P } & \begin{array}{l}\text { Postnatal day } \\ \text { PDX-1 }\end{array} \\ \text { Pancreatic and duodenal homeobox 1 } \\ \text { RIP } & \text { Rat insulin promoter }\end{array}$

\section{Introduction}

$\beta$-Catenin is found in adherens junctions, where it binds cadherins and establishes a link to the cytoskeleton through interaction with $\alpha$ - and $\gamma$-catenin [1]. Cytoplasmic $\beta$ catenin is phosphorylated and degraded by ubiquitinylation [2]. Upon activation by wingless and iNT-1 (WNT) factors, $\beta$-catenin is translocated into the nucleus, where it regulates the transcription of a variety of target genes, acting as a cofactor of the transcription factors $\mathrm{T}$ cell factor (TCF) and lymphoid enhancer factor (LEF), as reviewed by Nelson and Nusse [3].

WNT signalling members are present throughout pancreas development [4-8]. $\beta$-Catenin is present at the membrane of all pancreatic cells while active dephospho- 
$\beta$-catenin has been found in endocrine and exocrine tissues [9]. Overproduction of WNT1 and WNT5a causes pancreas agenesis or hypoplasia [5]. A dominant negative form of one of the WNT receptors, frizzled 8, induces severe pancreatic hypoplasia with decreased proliferation of pancreatic cells $[5,9]$. In the mouse embryo, deletion of $\beta$-catenin from all cells results in profound defects in anterior/posterior axis formation leading to embryonic death, whereas intercellular junctions are maintained [10]. Targeted deletion of $\beta$-catenin in pancreatic progenitors (pancreatic and duodenal homeobox $1[\mathrm{PDX} 1]^{+}$cells) was shown to inhibit growth of the exocrine tissue [11-13]. However, the effect on the endocrine compartment remains unclear. Deletion of $\beta$-catenin during pancreas development induces reversible pancreatitis and affects endocrine mass [11]. The same approach was used with a different Pdxl-Cre strain. The endocrine compartment developed normally in the absence of $\beta$-catenin in pancreatic progenitors [12, 13]. In addition, forced expression of active $\beta$-catenin at an early developmental stage led to major loss of exocrine and endocrine tissues, while late stabilisation of the protein resulted in enlarged exocrine compartment with normal endocrine mass [14]. Moreover, induced stabilisation of $\beta$-catenin by inactivation of the adenomatous polyposis coli gene (APC) (gene in all epithelial pancreatic cells led to pancreatomegaly due to acinar cell hyperplasia) [15]. Interestingly, the stabilisation of $\beta$-catenin in pancreatic beta cells (with rat insulin promoter [RIP]) was sufficient to induce islet mass increase, reflected by hyperinsulinaemia and improved glucose clearance in adults [16]. Targeted $\beta$-catenin stabilisation in the exocrine tissue was shown to promote pancreatic tumours [17]. Thus, most of the published work on $\beta$-catenin function in the pancreas was based on modulation of the expression of its gene in the progenitor compartment $\left(\mathrm{PDX}^{+}\right.$cells) or the exocrine compartment $\left(\mathrm{PTF}_{\mathrm{A}}{ }^{+}\right.$cells), which clearly showed its role in controlling exocrine tissue formation. However, although $\beta$ catenin does not seem to substantially impact on the development of pancreatic islets, its role in mature endocrine tissue requires further analysis [18].

At the functional level, data is scarcer. Most of the studies cited above either do not mention or report that no defects in glucose homeostasis or insulin secretion have been demonstrated. However, mice lacking the low-density lipoprotein receptor-related protein 5 (LRP5) WNT coreceptor showed impaired glucose homeostasis and glucose-induced insulin secretion [19]. Furthermore, mutations in the TCF4 gene are associated with type 2 diabetes and altered insulin secretion [20]. Very recently, TCF7L2 (TCF4) silencing was performed in isolated islets, impairing insulin secretion and affecting beta cell secretory machinery [21].
Since the timing of $\beta$-catenin presence seems critical during embryonic development, we deleted the $\beta$-catenin gene in insulin-producing beta cells, using a RIP-Cre/floxed $\beta$-catenin system. We then analysed the morphology and function of beta cells at neonatal stages.

\section{Methods}

Generation and maintenance of transgenic mice Mice were maintained in The Scripps Research Institute animal facility according to the rules enforced by the Institutional Animal Care and Use Committee of that organisation. Mice carrying a floxed allele of the $\beta$-catenin gene (referred to as $\operatorname{Catnb}^{\text {lox }}$ [22]) were obtained in the $\mathrm{C} 57 \mathrm{BL} / 6$ genetic background and crossed with the C57BL/6-TgN(Ins2-cre) 25Mng mouse strain (both from Jackson Laboratories, Bar Harbor, ME, USA), allowing expression of Cre recombinase gene under control of the RIP (referred to as RIP-Cre ${ }^{+}$ or $\mathrm{Cre}^{+}$[23]). Mice were genotyped by PCR according to the Jackson Laboratory's protocols. Catnb ${ }^{\text {lox/lox } / R I P-C r e^{+}}$ mice lack $\beta$-catenin in insulin-expressing cells. Control mice in this study were the Catnb $b^{\text {lox/lox }} / \mathrm{RIP}_{-} \mathrm{Cre}^{+}$littermates, namely, Catnb $b^{\text {lox/4 }} / \mathrm{Cre}^{+}$, Catnb ${ }^{\text {lox/+ }}$ and $\mathrm{Catnb}^{\text {lox/lox }}$ mice, but also mice bearing a wild-type Catnb (also known as Ctnnb1) locus and a Cre allele: $C_{a t n b^{+/+}} / \mathrm{Cre}^{+}$.

Tissue processing and staining Mouse pancreases were fixed in $10 \%$ neutral buffered formaldehyde (wt/vol.), embedded in paraffin and processed by routine histology procedures. The proportion of endocrine to total pancreatic tissue was evaluated after haematoxylin and eosin staining, and morphometric analysis with ImageJ 1.31 software was performed on seven animals in each group on at least three consecutive $5 \mu \mathrm{m}$ sections representing five levels of the pancreas [24]. For immunohistochemistry, the following primary antibodies were used: rabbit anti- $\beta$-catenin $(1: 500$; Sigma, St Louis, MO, USA), guinea pig anti-insulin $(1: 1,000$; Dako, Carpinteria, CA, USA), rabbit antiglucagon (1:200, Dako), rabbit anti-phospho histone 3 (1:100, Upstates, Billerica, MA, USA). Appropriate antirabbit biotinylated secondary antibodies and the Vectastain ABC-elite kit (Vector Laboratories, Burlingame, CA, USA) were used to detect the presence of $\beta$-catenin in adult pancreas. Diaminobenzidine (DAB) was used as a chromogen (Sigma). For double immunofluorescence staining, anti-rabbit-Texas Red or -FITC and anti-guinea pig-Texas Red (all from Vector) were incubated sequentially. Slides were mounted with Vectashield mounting solution with DAPI (Vector laboratories). Confocal images were taken using a laser scanning confocal microscope (Radiance 2100 Rainbow; BioRad, Hercules, CA, USA). 
The ratio of insulin-positive:glucagon-positive areas within islet clusters was determined with ImageJ 1.31 software (http://rsbweb.nih.gov/ij/) on sections from seven animals in each group. For each animal at least seven sections spanning the whole pancreas were analysed. Change in beta cell size was evaluated on the same confocal images by determining the number of nuclei (stained with DAPI) per insulin-positive area [25]. Apoptosis was detected by confocal microscopy using a kit (In Situ Cell Death Detection; Roche Molecular Biochemicals, Indianapolis, IN, USA).

Measurement of glucose, insulin and glucagon concentrations, and in vitro assay of insulin release Venous blood glucose levels were measured with a Glucometer Elite XL (Bayer, Tarrytown, NY, USA). Plasma insulin concentrations were determined by ELISA (Ultrasensitive Mouse Insulin ELISA; Alpco Diagnostics, Salem, NH, USA). Plasma glucagon was measured with a glucagon ELISA immunoassay (EIA) kit (Gentaur, Brussels, Belgium). Numeric data are mean $\pm \mathrm{SD}$. Neonatal pancreases were sonicated in $0.2 \mathrm{~mol} / 1 \mathrm{HCl}$ in ethanol and pancreatic insulin concentrations were determined by ELISA. Protein assays were performed with BCA Protein Assay (Pierce, Rockford, IL, USA).

Neonatal pancreases can be cultured as explants and release about 0.5 to $0.7 \mathrm{ng}$ insulin pancreas ${ }^{-1} \mathrm{~min}^{-1}$ [26]. Postnatal day (P) 1 or P2 neonatal pancreatic explants were weighed and cultured overnight in DMEM/F12 (Invitrogen, Carlsbad, CA, USA) containing 20\% fetal calf serum (vol./ vol.). The following day, they were tested for insulin release. They were pre-incubated for $3 \mathrm{~h}$ in Krebs medium [27]. They were challenged with 2 or $20 \mathrm{mmol} / \mathrm{l}$ of D-glucose for $1 \mathrm{~h}$. Insulin concentrations were measured in the media before and after glucose was added. Results are expressed as the mean fold increase of insulin in the medium after glucose infusion.

For glucose tolerance tests, overnight fasted 9- to 12 -week old mice were injected with D-glucose $(1 \mathrm{mg} / \mathrm{g}$ i.p.). Blood glucose levels were measured at the indicated times after the injection. Insulin tolerance tests were performed on 9- to 11-week old mice fasted for $3 \mathrm{~h}$, by injecting i.p. $0.75 \mathrm{U}$ of insulin per $\mathrm{kg}$ bodyweight. Results are expressed as percentage of the initial blood glucose value.

Statistical analyses Results are reported as mean \pm SD. The total number of animals tested in each group is indicated by $n$. To compare frequencies of genotypes and the distribution of blood glucose values, $\chi^{2}$ tests were performed. $F$ tests were used to compare variances between groups; means were compared using two-tailed unpaired Student's $t$ tests.

\section{Results}

A high percentage of newborn mice lacking $\beta$-catenin expression in the pancreatic beta cells die shortly after birth Mice containing a floxed $\beta$-catenin allele $\left(\right.$ Catn $b^{\text {lox }}$ [22]) were crossed with transgenic mice expressing the Cre recombinase gene under the control of the RIP2 promoter, allowing Cre-mediated recombination in pancreatic beta cells [23]. To obtain mice bearing the floxed $\beta$-catenin gene in both alleles, the $C a t n b^{l o x /+} / R I P-C r e^{+}$mice were intercrossed with Catnb $^{\text {lox/+ }}$ mice. Surprisingly, the Catnb $b^{\text {lox/lox } /}$ RIP-Cre ${ }^{+}$mice did not have the expected Mendelian distribution. Table 1 shows that only $4.7 \%$ of weaned $\mathrm{Catnb}^{\text {lox/lox }} / \mathrm{RIP}-\mathrm{Cre}^{+}$mice were obtained. In an attempt to increase the percentage of Catnb $b^{\text {lox/lox }} / \mathrm{RIP}-\mathrm{Cre}^{+}$mice, we crossed $\mathrm{Catnb}^{\text {lox/+}} / \mathrm{Cre}^{+}$mice with $\mathrm{Catnb}^{\text {lox/lox }}$ mice. Again, instead of obtaining the expected $25 \% \mathrm{Catnb}^{\text {lox } / l o x} / \mathrm{RIP}$ $\mathrm{Cre}^{+}$viable adult progeny, a significantly reduced percentage $(9 \%)$ was obtained ( $p=0.003$ by $\chi^{2}$ test) (Table 2$)$. This indicates that about $70 \%$ of the Catnb ${ }^{\text {lox } / \text { lox }} / \mathrm{RIP}-\mathrm{Cre}^{+}$mice died before weaning. To determine whether Catnb $b^{\text {lox/lox } /}$ RIP-Cre ${ }^{+}$embryos were viable through embryogenesis, we performed genotyping of $\mathrm{Catnb}^{\text {lox/+}} / \mathrm{RIP}-\mathrm{Cr}^{+} \times \mathrm{Catnb}^{\text {lox/lox }}$ intercrosses at prenatal stages (embryonic days 19-20). $\mathrm{Catnb}^{\text {lox/lox} / R I P-C r e} e^{+}$animals were retrieved at the expected percentage rate $\left(23 \%, p=0.19\right.$ by $\chi^{2}$ test $)$ (Table 2), suggesting that the Catn $b^{\text {lox/lox}} /$ RIP-Cre $^{+}$die early after birth. To test this hypothesis, we determined the distribution of the progeny of the Catnb $b^{l o x /+} / \mathrm{RIP}_{-} \mathrm{Cr} \mathrm{C}^{+} \times$

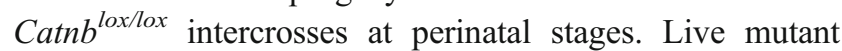
mice were retrieved at the expected rate at $\mathrm{P} 1$, but they rapidly died between $\mathrm{P} 1$ and $\mathrm{P} 2 \quad(p<0.003)$ (Table 2). Interestingly, at P1 all animals appeared normal and seemed normally fed. No difference was observed in the size or body weight between mutants and their littermates (data not shown).

Table 1 Genotype of progeny from Catn $^{\text {lox/+ }} / \mathrm{Cre}^{+}$intercrosses

\begin{tabular}{lcl}
\hline Progeny & \multicolumn{2}{l}{ Parents } \\
\cline { 2 - 3 } & \multicolumn{2}{l}{ Catnb $^{\text {lox/+}} / \mathrm{Cre}^{+} \times$Catn $^{\text {lox } /+}$} \\
\cline { 2 - 3 } & Obtained, \% (n) & Expected distribution $^{\text {a }}(\%)$ \\
\hline Catnb $^{+/+}$ & $11.9(20)$ & 12.5 \\
Catnb $^{+/+} / \mathrm{Cre}^{+}$ & $13.7(23)$ & 12.5 \\
Catnb $^{\text {lox/+ }}$ & $27.4(46)$ & 25 \\
Catnb $^{\text {lox/+}} / \mathrm{Cre}^{+}$ & $25.6(43)$ & 25 \\
Catnb $^{\text {lox/lox }}$ & $16.7(28)$ & 12.5 \\
Catnb $^{\text {lox/lox } / \mathrm{Cre}^{+}}$ & $4.7(8)$ & 12.5 \\
\hline
\end{tabular}

The genotypes were determined by specific PCRs on DNA extracted from tails of weaned pups

${ }^{\text {a }}$ According to Mendelian laws 


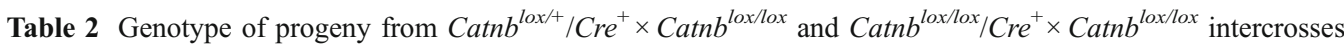

\begin{tabular}{|c|c|c|c|c|c|c|c|c|c|}
\hline \multirow[t]{3}{*}{ Progeny } & \multicolumn{9}{|l|}{ Parents } \\
\hline & \multicolumn{5}{|c|}{$\mathrm{Catnb}^{\text {lox/+ }} / \mathrm{Cre}^{+} \times \mathrm{Catnb}^{\text {lox/lox }}$} & \multicolumn{4}{|c|}{$\mathrm{Catnb}^{\text {lox/lox}} / \mathrm{Cre}^{+} \times \mathrm{Catnb}^{\text {lox/lox }}$} \\
\hline & $\begin{array}{l}\text { Adults } \\
\text { obtained }^{\mathrm{a}} \text {, } \\
\%(n)\end{array}$ & $\begin{array}{l}\text { E19-20, \% } \\
(n)\end{array}$ & $\begin{array}{l}\mathrm{P} 1, \% \\
(n)\end{array}$ & $\begin{array}{l}\mathrm{P} 2^{\mathrm{a}}, \% \\
(n)\end{array}$ & Expected $^{\mathrm{b}}$ & $\begin{array}{l}\text { Adults } \\
\text { obtained }^{\mathrm{a}} \text {, } \\
\%(n)\end{array}$ & $\begin{array}{l}\mathrm{P} 1, \% \\
(n)\end{array}$ & $\begin{array}{l}\mathrm{P}^{\mathrm{a}}, \% \\
(n)\end{array}$ & Expected $^{\mathrm{b}}$ \\
\hline Catnb $^{l o x /+}$ & $30(34)$ & $26.7(12)$ & $27.1(28)$ & $27.3(12)$ & 25 & NA & NA & NA & NA \\
\hline $\mathrm{Catnb}^{\operatorname{lox} /+} / \mathrm{Cre}^{+}$ & $32(38)$ & $17.1(8)$ & $26.2(29)$ & $31.8(14)$ & 25 & NA & NA & NA & NA \\
\hline $\operatorname{Catnb}^{\operatorname{lox} / l o x}$ & $29(30)$ & $29.8(14)$ & $18.7(20)$ & 31.8 (14) & 25 & $71.4(20)$ & ND & $60.9(12)$ & 50 \\
\hline $\operatorname{Catn}^{\text {lox } / l o x} / \mathrm{Cre}^{+}$ & $9(11)$ & $23.4(11)$ & $28(30)$ & $9.1(4)$ & 25 & $28.6(8)$ & ND & $39.1(9)$ & 50 \\
\hline
\end{tabular}

The genotypes were determined by specific PCRs on genomic DNA extracted from tails ${ }^{\text {a }} p \leq 0.003 \chi^{2}$ test results

${ }^{\mathrm{b}}$ According to Mendelian laws

E19-20, embryonic day 19 or 20; NA, not available; ND: not determined

The efficiency of $\beta$-catenin deletion was tested in the pancreases of newborns and surviving adults. In $C a t n b^{\text {lox/lox/ }}$ $\mathrm{RIP}-\mathrm{Cre}^{+}$islets, membrane $\beta$-catenin staining was absent in the cells containing insulin (Fig. 1d-f). Other areas of the pancreas displayed $\beta$-catenin and were indistinguishable from wild-type mice (Fig. 1a-c). Two-month old Catn $b^{\text {lox/lox/ }}$ $\mathrm{RIPCre}^{+}$mice showed reduced levels of $\beta$-catenin by

Fig. 1 RIP2-Cre-driven $\beta$ catenin deletion is efficient in pancreatic insulin-positive cells. Neonatal pancreas sections of control $(\mathbf{a}-\mathbf{c})$ and Catnb ${ }^{\text {lox } / l o x} /$ $\mathrm{RIP}-\mathrm{Cre} e^{+}(\mathbf{d}-\mathbf{f})$ were stained with anti- $\beta$-catenin (green) and anti-insulin (red). c, $\mathbf{f}$ Merges of confocal images showing that the majority of neonatal beta cells lack $\beta$-catenin in $\mathrm{Catnb}^{\text {lox/lox }} / \mathrm{RIP}-\mathrm{Cre}^{+}$mice (f) compared with control mice (c). Original magnification: $\times 630$. $\mathrm{g}$ Western blot of islet protein extracts showing that $\beta$ catenin signal was decreased in mutant islets $(\mathrm{KO})$ compared with wild-type (WT), the residual signal being the result of $\beta$-catenin presence in nonbeta cells within the islets. i Adult mutant pancreases displayed drastic loss of $\beta$-catenin immunoreactivity revealed with $\mathrm{DAB}$, whereas all islet cells exhibited $\beta$-catenin immunopositivity in control (h). Inserts, pancreatic ducts remained positive for $\beta$-catenin. Original magnification: $\times 400$

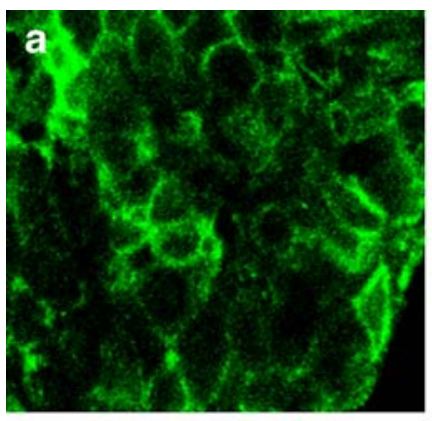

western blotting of islet protein extracts (Fig. 1g). The remaining band may reflect the maintenance of $\beta$-catenin content in non-beta cells within the islets. B-catenin deletion in surviving adults was also evident by immunohistochemistry (Fig. 1h, i) and seemed to affect the majority of the islet cells. Moreover, the duct epithelium retained $\beta$-catenin production (Fig. 1h, i). These results demonstrate that $\beta$ -
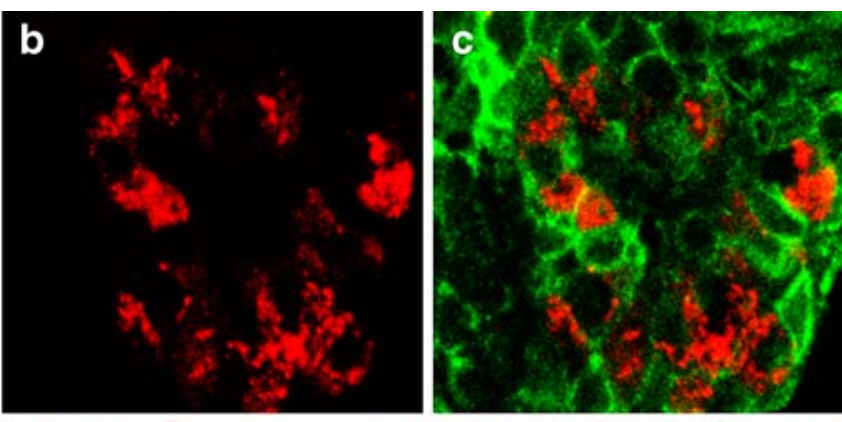
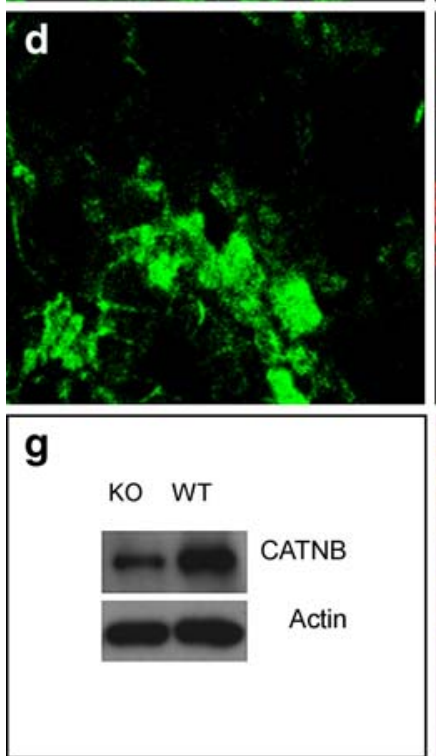
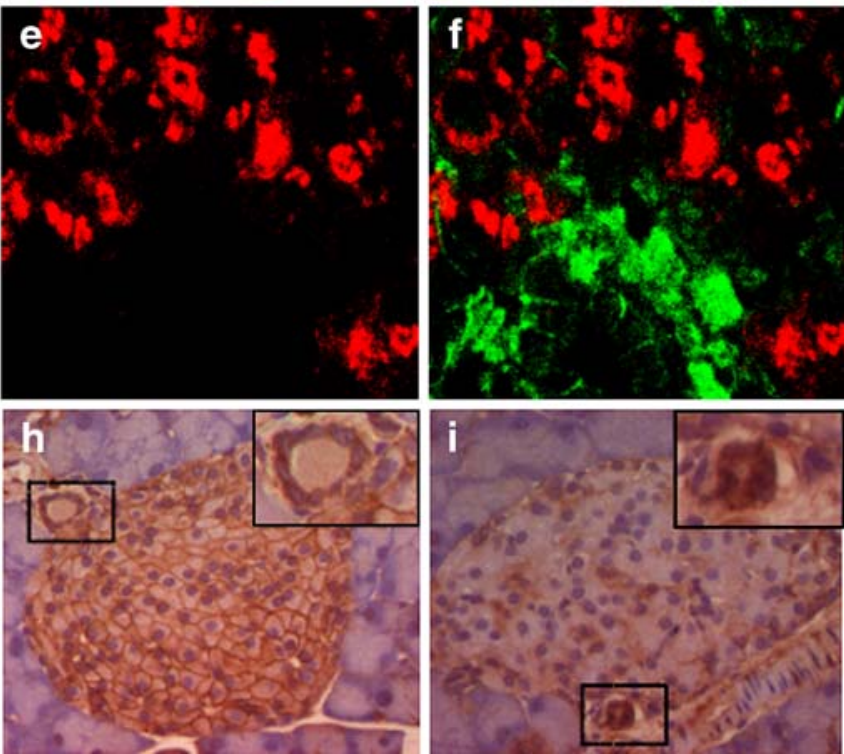
Table 3 Glycaemia-related variables in newborn animals

\begin{tabular}{|c|c|c|c|c|c|c|c|c|c|}
\hline Genotype per time point & Glucose $(\mathrm{mmol} / \mathrm{l})$ & $n$ & $p$ value & Insulin (pmol/1) & $n$ & $p$ value & Glucagon (ng/l) & $n$ & $p$ value \\
\hline \multicolumn{10}{|l|}{$\mathrm{P} 1$} \\
\hline $\operatorname{Catnb}^{\operatorname{lox} / \mathrm{lox}} / \mathrm{Cre}^{+}$ & $2.78 \pm 1.52$ & 22 & & $58.6 \pm 44.8$ & 17 & & $192.5 \pm 27.6$ & 18 & \\
\hline Catnb $^{\text {lox/lox }}$ & $2.87 \pm 1.00$ & 38 & 0.009 & $87.9 \pm 36.2^{\mathrm{a}}$ & 23 & 0.037 & $210.3 \pm 44.4$ & 7 & 0.17 \\
\hline $\mathrm{Catnb}^{+/+} / \mathrm{Cre}^{+}$ & $3.01 \pm 0.80^{\mathrm{a}}$ & 11 & 0.047 & NA & NA & NA & $161.1 \pm 27.4^{\mathrm{a}}$ & 7 & 0.04 \\
\hline \multicolumn{10}{|l|}{$\mathrm{P} 2$} \\
\hline Catnb $^{\operatorname{lox} / \text { lox }} / \mathrm{Cre}^{+}$ & $3.49 \pm 1.29$ & 18 & & $153.4 \pm 58.6$ & 6 & & $224.5 \pm 59$ & 7 & \\
\hline $\operatorname{Catnb}^{\text {lox/lox }}$ & $3.62 \pm 1.09$ & 34 & 0.699 & $131.0 \pm 53.4$ & 8 & 0.46 & $179.9 \pm 12.9^{\mathrm{a}}$ & 9 & 0.04 \\
\hline $\mathrm{Catnb}^{+/+} / \mathrm{Cre}^{+}$ & $4.18 \pm 0.69$ & 8 & 0.17 & NA & NA & NA & $162.9 \pm 10.3^{\mathrm{a}}$ & 6 & 0.03 \\
\hline
\end{tabular}

Values are means $\pm \mathrm{SD}$ of $\mathrm{P} 1$ and $\mathrm{P} 2$ animals according to their genotypes

Note that on P1 the SD obtained for glucose values of mutant animals $\left(\right.$ Catn $\left.b^{\text {lox } / l o x} / \mathrm{Cre}^{+}\right)$was very high, suggesting a high variability in the mutant blood glucose values. Analysis of variances $\left(F\right.$ test) against $C a t n b^{\text {lox } / l o x} / C_{r} e^{+}$values confirmed the abnormal distribution of mutant blood glucose values $(p \leq 0.05)$, whereas mean values were not different (Student's $t$ test)

$p$ values of $\mathrm{Catnb}^{+/+} / \mathrm{Cre}^{+}$or $\mathrm{Catnb}^{\text {lox/lox }}$ against $\mathrm{Catn}^{\text {lox/lox }} / \mathrm{Cre}^{+}$values are with Student's $t$ test, except for P1 glucose ( $F$ test)

${ }^{a} p \leq 0.05$ compared with $\mathrm{Catnb}^{\text {lox/lox}} / \mathrm{Cre}^{+}$values

NA, not available

catenin deletion is efficient in pancreatic beta cells of mutant mice.

$\beta$-Catenin depletion in insulin producing cells causes erratic glycaemia and insulinaemia in neonates Since the high incidence of postnatal death of the $\mathrm{Catnb}^{\text {lox/lox } / R I P-C r e} e^{+}$ mice occurred early after birth, we looked at blood glucose or insulin levels in $\mathrm{Catnb}^{\text {lox/lox}} / \mathrm{RIP}_{-\mathrm{Cr} e^{+}}$mice. On the day of birth (P1), the mean values for blood glucose were comparable in $\mathrm{Catnb}^{\text {lox/lox} / R I P-C r e} e^{+}$and control neonates (Table 3). Control groups bearing the $\mathrm{Cre}$ allele, i.e. $\mathrm{Catnb}^{+/+} / \mathrm{Cre}^{+}$and $\mathrm{Catnb}^{\text {lox/+ }} / \mathrm{Cre}^{+}$(latter not shown), displayed values similar to those obtained for the $\operatorname{Catnb}^{\text {lox/4 }}$ (not shown) and the
Catnb $^{\text {lox/lox }}$ groups (Table 3). However, a comparison of variances between the mutant group and the control groups showed that, in the absence of $\beta$-catenin, the distribution of the individual values was very erratic in the former $(\mathrm{p}=0.009$ 0.05 by $F$ test) (Table 3 ). Whereas about 75 to $80 \%$ of the $\mathrm{Catnb}^{\text {lox/lox }}$ and $\mathrm{Catnb}^{+/+} / \mathrm{Cre}^{+}$animals displayed normal blood glucose values ranging from 2.22 to $4.44 \mathrm{mmol} / \mathrm{l}$, only about $40 \%$ of the mutant pups were in that range $(p<0.001$ by $\chi^{2}$ test) (Fig. 2a). Consequently, the number of mice exhibiting lower or higher glycaemia was doubled in the mutant mice population (Fig. 2a). At P2, the remaining Catnb $^{\text {lox/lox}} /$ RIP-Cre $^{+}$pups were normoglycaemic (Table 3). This suggests that the erratic distribution of mutant values a
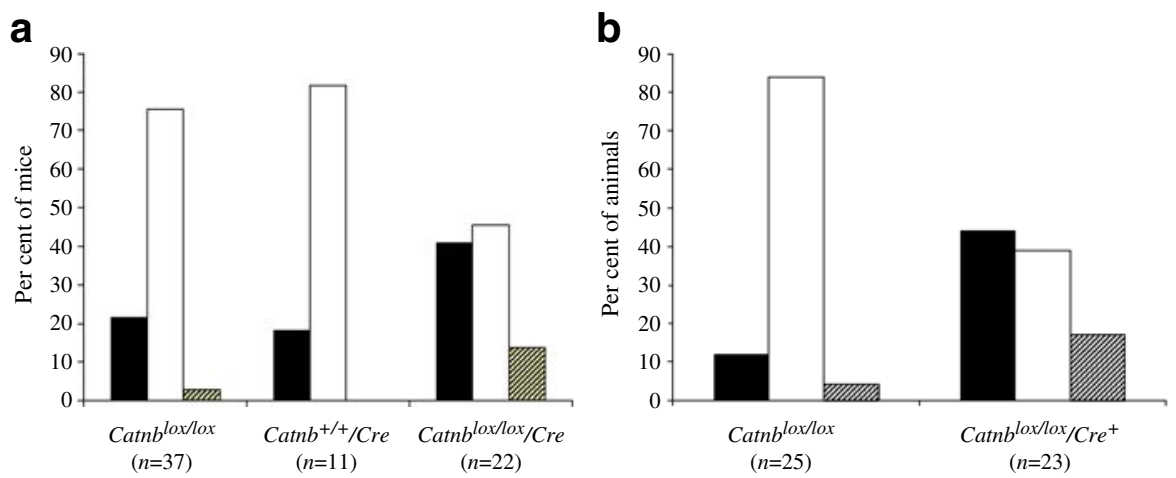

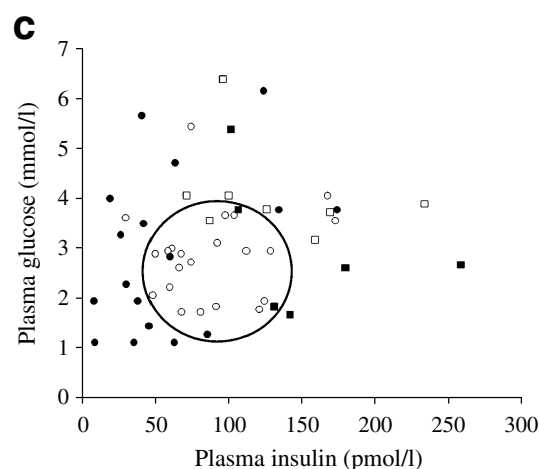

Fig. $2 \beta$-Catenin depletion in insulin producing cells causes abnormal glycaemia and insulinaemia. a The blood glucose values of P1 control and Catnb $b^{l o x / l o x} / R I P-C r e^{+}$neonates were distributed according to the following scheme: $<2.2 \mathrm{mmol} / \mathrm{l}$ (black bars); $2.3-$ $4.3 \mathrm{mmol} / 1$ (white bars); $4.4 \mathrm{mmol} / 1$ and higher (hatched bars). $p<$ 0.001 compared with the indicated control groups $\left(\chi^{2}\right.$ test), suggesting that P1 mutant mice presented a highly perturbed glucose homeostasis. b The plasma insulin values of P1 control and $\mathrm{Catnb}^{\text {lox/lox }} / \mathrm{RIP}_{-} \mathrm{Cre}^{+}$neonates were distributed according to the following scheme: $<51.7 \mathrm{pmol} / \mathrm{l}$ (black bars); 51.8-172.3 pmol/1 (white bars); $172.4 \mathrm{pmol} / 1$ and higher (hatched bars). $p<0.001$ between the two groups, suggesting that P1 mutant mice had deregulated insulinaemia. c Plasma insulin values plotted against plasma blood glucose values in P1 (white circles) and P2 (white squares) control and P1 (black circles) and P2 (black squares) Catnb $b^{\text {lox/lox }} / R I P-C r e^{+}$neonates. The majority of the control values are encircled, showing that the mutant values do not cluster in the same region of the graph 
seen at P1 is corrected, probably by the death of the hypoglycaemic pups.

We measured plasma insulin concentrations on P1 and P2. Catn $b^{\text {lox/lox }} / \mathrm{RIP}_{\mathrm{C}-\mathrm{Cre}}{ }^{+}$animals showed decreased insulin concentration on P1 compared with the Catnb $b^{l o x / l o x}$ mice (Table 3). In addition, at this stage, a large proportion of the mutant values (about 45\%) were below $51.7 \mathrm{pmol} / \mathrm{l}$ of insulin (detection limit of the method employed) compared with $12 \%$ for the control values $\left(p<0.001, \chi^{2}\right.$ test $)$ (Fig. 2b). On P2 no differences in mean plasma insulin concentrations were observed. Very interestingly, when insulin levels were plotted against blood glucose concentrations, the mutant values were scattered, with few being in the same area as the control population whereas most of the control values were clustered (Fig. 2c). Since glucose homeostasis also depends on glucagon, we tested plasma glucagon levels. On P1, glucagon concentrations were significantly higher in the mutant pups than in the $\mathrm{Catnb}^{+/+} / \mathrm{RIP}_{-\mathrm{Cre}} \mathrm{C}^{+}$group (Table 3). However, this result was not observed when the mutant group was compared with the $C a t n b^{\text {lox/lox }}$ control group. Interestingly, however, the mutant values on $\mathrm{P} 2$ were mildly but significantly higher in the $C a t n b^{\text {lox/lox }} / \mathrm{RIP}_{\mathrm{C}} \mathrm{Cr} e^{+}$group, with results for both control groups reaching significance (Table 3). As for insulin values, no correlation between glucose and glucagon values was observed in the mutant group (data not shown).

Thus, the regulation of plasma insulin and glucagon was impaired in the Catn $b^{\text {lox/lox}} / \mathrm{RIP}_{-} \mathrm{Cre}^{+}$neonates, triggering highly disturbed glucose homeostasis, hypoglycaemia and lethality early after birth, between P1 and P2.

$\beta$-Catenin-depleted beta cells are reduced in size The gross morphology, mass and size of the mutant pancreas appeared normal (data not shown). Histological examination revealed that control and Catnb $b^{\text {lox } / l o x} / R I P-C r e^{+}$pancreases displayed similar overall organisation (Fig. 3a, b). Islets could be identified and the adhesion molecules that interact with $\beta$ catenin were present in the deficient mice (E-cadherin and plakoglobin, data not shown).

However, morphometric analysis revealed that the proportion of endocrine tissue was diminished in Catnb $b^{\text {lox/lox } /}$ RIP-Cre ${ }^{+}$newborn mice $(p=0.025)$ (Fig. 3a-c). Noticeably, the ratio of the insulin-positive cell area to the number of nuclei, representing beta cell density [25] and average cell size $[28,29]$, was also significantly reduced in the mutant newborn pancreases compared with control
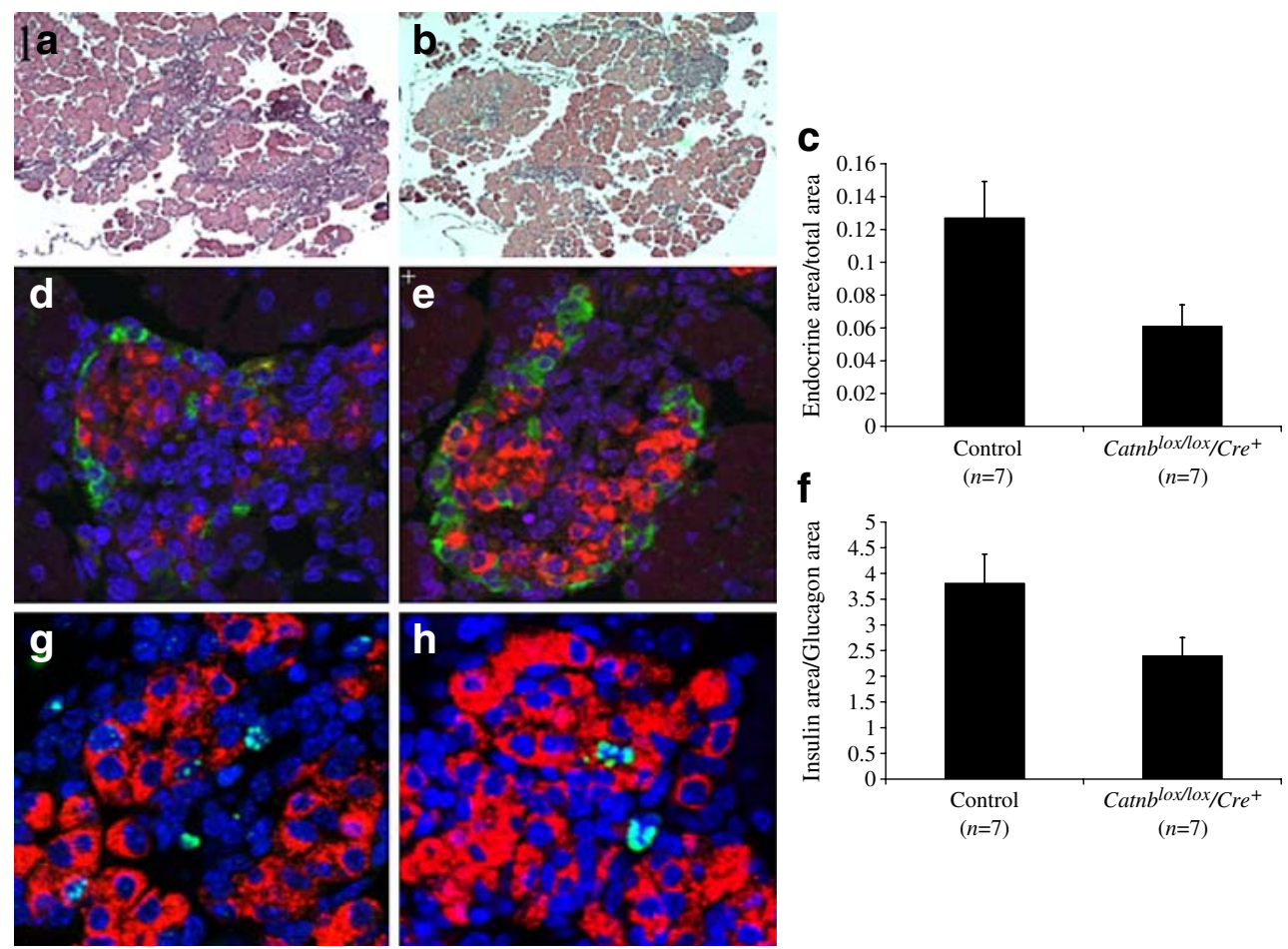

Fig. 3 RIP2-Cre-driven $\beta$-catenin deletion leads to the formation of immature beta cells. Control Catnb $b^{\text {lox/lox }}(\mathbf{a}, \mathbf{d}, \mathbf{g})$ and $\mathrm{Catnb}^{\text {lox/lox}} / \mathrm{RIP}$ $\mathrm{Cre}^{+}(\mathbf{b}, \mathbf{e}, \mathbf{h})$ newborn pancreases (P1) were stained with haematoxilin and eosin $(\mathbf{a}, \mathbf{b})$ (original magnification: $\times 100)$ or confocal images were made (original magnification: $\times 630$ ) after specific immunodetection with anti-insulin (red) and anti-glucagon (green) (d, e), and with anti-insulin and anti-phospho histone 3 (green) (g, h). DAPI (blue) was used in the mounting solution to visualise nuclei $(\mathbf{d}, \mathbf{e}, \mathbf{g}$, h). c Mutant newborns displayed a significant reduction in the endocrine area:total pancreatic area ratio $(p=0.025)$ and (f) in the ratio of insulin-positive:glucagon-positive area $(p=0.013)$. However, the distribution of proliferating insulin-positive cells appeared similar in both groups $(\mathbf{g}, \mathbf{h})$ 
a

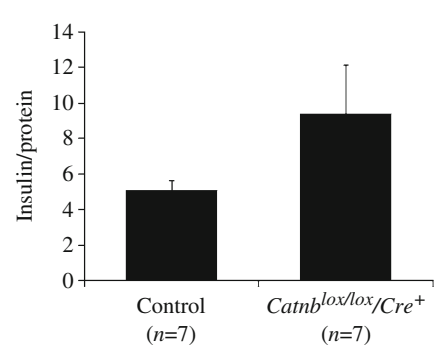

b

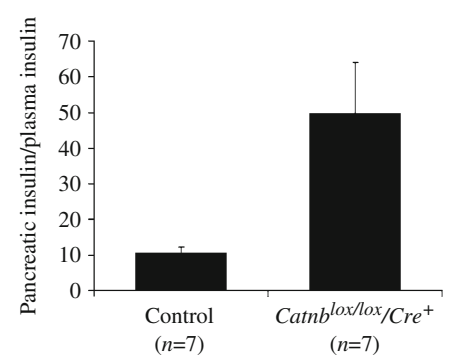

C

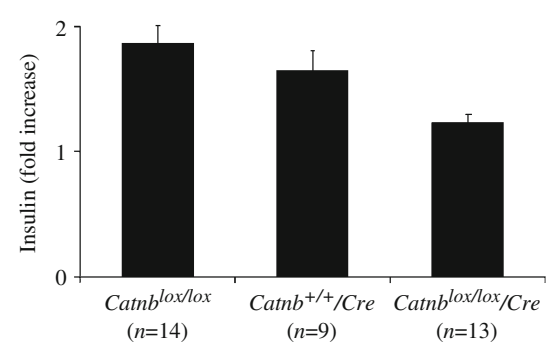

Fig. 4 Although insulin content is increased in pancreases of mice lacking $\beta$-catenin, they fail to release insulin in vitro. a Total pancreatic insulin content of P1 neonates was determined as described, $p=0.03$. b The ratio of pancreatic insulin:plasma insulin, $p=0.019$. c P1 pancreas explants were cultured overnight and

littermates $\left(67.5 \pm 10.5 \mu \mathrm{m}^{2} \quad n=10\right.$ and $75.5 \pm 13.9 \mu \mathrm{m}^{2}$ $n=5$, respectively, $p=0.01$ ). In addition, the ratio of insulin-positive area/glucagon-positive area was lower in the mutant mice ( $p=0.013, n=7$ in each group) (Fig. $3 \mathrm{~d}-$ f). The frequency of islet clusters and apoptotic cells was similar in mutant and wild-type pancreases, suggesting that islet differentiation is not affected by lack of $\beta$ catenin (data not shown). To test whether the changes in cell density reflected changes in beta cell mitosis, we carried out double immunofluorescence staining of insulin and phospho-histone 3, immunoreactivity to which was similar in both groups (Fig. 3g, h). Thus, deletion of $\beta$ catenin in the beta cells causes apparent loss of endocrine tissue due to the presence of smaller pancreatic beta cells, rather than a loss of total beta cell number.

$\beta$-Catenin-depleted beta cells fail to release insulin The $\mathrm{Catnb}^{\text {lox/lox} / R I P-C r e^{+}}$pancreases displayed an approximately twofold increase in total pancreatic insulin content on P1 $(p=0.03, n=7)$ (Fig. 4a). However, this augmentation did not correlate with higher plasma insulin levels, since the ratio of pancreatic insulin/plasma insulin was markedly increased by fivefold ( $p=0.019$ ) (Fig. $4 \mathrm{~b}$ ). In contrast, as mentioned above, plasma insulin levels in mutants on P1 were lower (Table 3). This suggests that on P1 insulin release is defective in the absence of $\beta$-catenin. To test this hypothesis, P1 neonatal pancreatic explants were challenged in vitro with $20 \mathrm{mmol} / \mathrm{l}$ of glucose in glucose-free medium. The pancreases from $\mathrm{Catnb}^{\text {lox } / \text { ox }} / \mathrm{RIP}_{-} \mathrm{Cre}^{+}$mice failed to release appropriate amounts of insulin in the medium compared with control pancreases $(n=13, n=14$ and $n=6$, respectively, $p<0.001$ ) (Fig. $4 \mathrm{c}$ ).

Phenotype of surviving $\beta$-catenin-deleted adult mice The surviving adult $\mathrm{Catnb}^{\text {lox/lox}} / \mathrm{RIP}-\mathrm{Cre}^{+}$mice were normoglycaemic and displayed normal levels of plasma insulin and pancreas and islet architecture. The number and size of islets were similar in mutant and wild-type groups. challenged with $20 \mathrm{mmol} / \mathrm{l}$ of D-glucose. The fold increase of insulin in media is shown for Catnb $b^{\text {lox/lox }}$, Catnb $^{+/+} /$RIP-Cre $^{+}$and Catnb ${ }^{\text {lox/lox }} /$ $R I P-C r e^{+}$pancreatic explants; $p<0.001$ for mutant animals against both control groups

Moreover, islet cellularity and total insulin content seemed unaffected by lack of Catnb gene. However, when fasted and challenged with glucose, a mild intolerance to glucose was observed $(n=16)$ (Fig. 5a). The abnormal glucose clearance was accentuated when the $\operatorname{Catn} b^{\text {lox } / \text { lox }} / \mathrm{Cre}^{+}$ animals were compared with the $\mathrm{Catnb}^{+/+} / \mathrm{Cre}^{+}$group ( $n=$ 5-6) (Fig. 5b). Because a great number of mutant pups displayed low glucose and low insulin, it was quite possible that Catn $^{\text {lox } / \text { lox }} / \mathrm{Cre}^{+}$animals showed increased insulin sensitivity. However, it was very difficult to test that variable in newborn on P1. Thus, to assess insulin sensitivity, we tested the response of adult mice to insulin
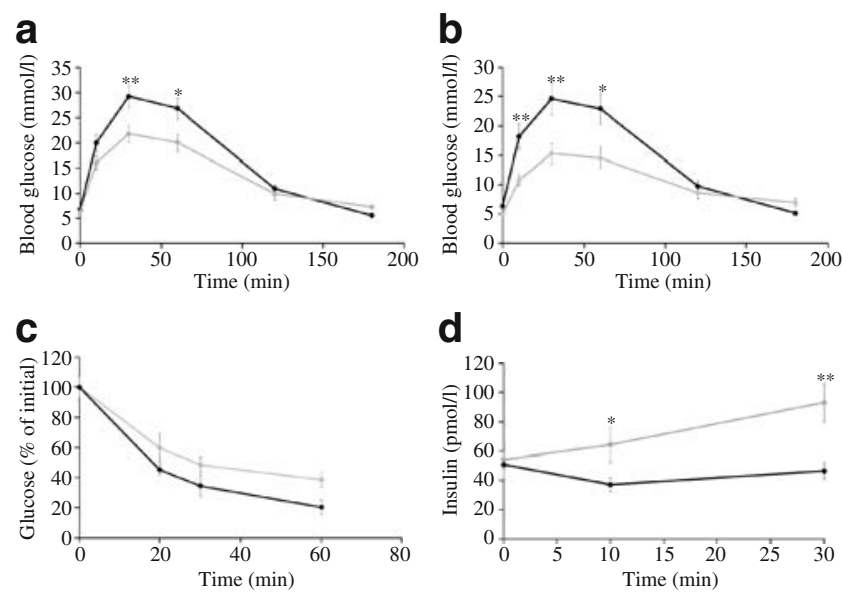

Fig. 5 Adult mutant mice displayed a mild glucose intolerance phenotype. a Glucose tolerance tests were performed on 9- to 12 -week-old mice. Results are mean $\pm \mathrm{SEM}$ from three pooled independent experiments on 12 Catn $b^{\text {lox } / \text { lox }} / \mathrm{Cre}^{+}$animals (black line) and $16 \mathrm{Catnb}^{+++} / \mathrm{Cre}^{+}$and Catnb $b^{\text {lox/lox }}$ mice (grey line). b Two pooled experiments on five $\mathrm{Catnb}^{\text {lox/lox}} / \mathrm{Cre}^{+}$animals and six $\mathrm{Catnb}^{+/+} / \mathrm{Cre}+$ showing that the observed intolerance was due to lack of $\beta$-catenin and not to the presence of the Cre gene in the beta cells. $\mathbf{c}$ Insulin tolerance tests were performed during two independent experiments on eight Catn $^{\text {lox/lox}} / \mathrm{Cre}^{+}$mutant (black line) and seven $\mathrm{Catnb}^{+/+} / \mathrm{Cre}^{+}$wild-type mice (grey line) at 9 to 11 weeks of age. Data are mean \pm SD percentage of initial glucose concentration. d Glucose-induced insulin release, mean \pm SD. ${ }^{*} p<0.05, * * p=<0.01$ 
injection. Although the mutant values were modestly lower, comparison of the mean values was not statistically significant (Fig. 5c). Thus, the absence of $\beta$-catenin in the beta cells does not overtly impact on insulin tolerance in the periphery but does induce mild glucose intolerance in adults. The impaired glucose clearance was explained in adult mutant mice by defective glucose-induced insulin release (Fig. 5d).

\section{Discussion}

We examined for the first time the effect of targeted $\beta$ catenin deletion in insulin-expressing pancreatic beta cells at perinatal stages. Although the RIP2 promoter is active as early as 11.5 days past conception [30], developmental stages were not considered since $\mathrm{Catnb} b^{\text {lox/lox }} / \mathrm{RIP}-\mathrm{Cre}^{+}$ animals were retrieved at the expected Mendelian rates. Importantly, lack of $\beta$-catenin was frequently fatal early after birth, probably because of severe hypoglycaemia. Previous studies with $\beta$-catenin deletion did not report increased mortality; however, animal survival was not stated. Moreover, consistent with our findings, a third recent paper reports that mice lacking $\beta$-catenin in $P d x 1$ expressing cells have increased mortality rates later in life (median survival 29 days) [13]. Noticeably, $P d x$-1-driven Cre expression leads to mosaicism of Cre penetrance [31, 32]. By contrast, the RIP2 promoter achieves $>95 \%$ efficiency of Cre expression in mature pancreatic beta cells. In addition, deletion of the targeted gene increases at perinatal stages, as the insulin-producing cells mature into fully differentiated beta cells [23, 32-34], which may be critical for expression of the phenotype. This notion is further supported by the observation of huge impact of the timing of $\beta$-catenin deletion on beta cells phenotype. Mosaic expression of PDX1-Cre in adult islets was observed with no significant change in beta cell mass when stabilising $\beta$-catenin in $\mathrm{PDX}^{+}$cells [14]. With RIP-Credriven stabilisation however, beta cell expansion was observed [16]. Thus, the lethality and the beta cell secretory defects in newborns observed here may be accounted for by the timing and magnitude of the deletion of $\beta$-catenin in the insulin-producing cells at a juncture when glucose homeostasis becomes crucial for survival. On perinatal day 2 , the surviving Catnb ${ }^{\text {lox/lox }} / \mathrm{RIP}-\mathrm{Cre}^{+}$mice seemed to have recovered normal insulin levels and glycaemia. In parallel, glucagon level was increased, suggesting that the Catnb ${ }^{\text {lox/lox }}$ $\mathrm{RIP}-\mathrm{Cr} e^{+}$pups restored normal glycaemia by adjusting their glucagon levels. It is worth mentioning here that none of the previous studies reports the levels of glucose or insulin in newborn mice.

The modulation of WNT signalling in the endocrine pancreas is deleterious for its formation, as reviewed [18].
Beta cells lacking $\beta$-catenin are smaller than control cells. Consistently, when overexpressing a soluble form of the frizzled 8 receptor, the number of endocrine cells per pancreatic area was increased in the mutant mice, while the overall number of endocrine cells was decreased [9]. This could reflect a reduction in the size of islet cells (alpha and beta, since the proportion of beta to alpha cells was conserved). Augmentation of pancreatic cellular density was reported when $\beta$-catenin gene expression was disturbed [5, 14]. Collectively, these results suggest that the modulation of WNT signalling affects the size of pancreatic epithelial cells and that the timing of $\beta$-catenin modulation is critical for this effect. In the same way, $\beta$-catenin has been shown to control the size of cardiac cells. Thus stabilisation of $\beta$-catenin augmented cell ploïdy and resulted in hypertrophy of mouse cardiomyocytes and fibroblasts [35]. Similarly, deletion of $\beta$-catenin in the same cells resulted in the same effect [36]. The decreased beta cell size observed here could be a reflection of beta cell immaturity, as maturation of pancreatic beta cells involves a gain in cell volume [37] and the islet cellularity of the surviving Catnb $b^{\text {lox/lox }} / \mathrm{RIP}-\mathrm{Cre}^{+}$adults was normal. Consistently, a defect in beta cell functional maturation in the absence of $\beta$-catenin is compatible with the metabolic disorders observed at early postnatal stages, where islet maturation is not fully completed. Indeed, normal neonate pancreases show impaired glucose-induced insulin secretion as compared with adults. This study shows that beta cells are morphologically immature (see below). Thus, lack of $\beta$-catenin may delay beta cell maturation, which results in abnormal glycaemia and insulinaemia owing to beta cell dysfunction. In the same way, the increased glucagon levels observed in mutants may reflect a response to counteract hypoglycaemia, but which was not sufficient to correct glucose homeostasis in the majority of the $\mathrm{Catnb}^{\text {lox/lox }} / \mathrm{RIP}$ $\mathrm{Cre}^{+}$newborns. Further investigations will be needed to determine the exact molecular mechanisms by which $\beta$ catenin regulates pancreatic beta cell growth. However, it is more likely that this effect is Wnt-dependent than related to $\beta$-catenin structural function in adherens junctions. Indeed other members of the Wnt pathway can regulate cell size such as Wnt10b [38] or Wnt1 [39].

Indirect attenuation of WNT signals by overexpression of a frizzled8 dominant negative in the pancreas led to developmental defects [9]. However, the adult mice were normoglycaemic and displayed normal response to glucose challenge at 10 to 12 weeks of age, but had increased pancreatic insulin content. Similarly, the deletion of $\beta$ catenin in pancreatic progenitors $\left(\mathrm{PDX} 1^{+}\right)$does not lead to abnormal glycaemia in adults or significant impaired glucose tolerance [11-13]. In the present work, the surviving adult $\mathrm{Catnb}^{\text {lox/lox}} / \mathrm{RIP}-\mathrm{Cre}^{+}$mice were normoglycaemic and had normal insulinaemia, but mild glucose 
intolerance and defective glucose-induced insulin secretion. However, whereas results in the literature appear to be in contrast with our findings, direct comparisons among all of these studies are difficult. For example, Dessimoz et al. [11] used relatively young mice ( 6 weeks old) and no $n$ value was given. Wells et al. [13] used 6-month old mice, but only three in each group, and did not perform any glucose tolerance test. Murtaugh et al. showed convincing glucose tolerance test results done on 12- to 15- month old mice [12], with no difference between mutant and wild-type mice. However, the expression of the phenotype can be age-dependent, as for LRP5 deletion where glucose intolerance was not seen before 6 months of age, the fasting animals being normoglycaemic [19]. Moreover, since PDX1 promoter activity showed mosaicism, a high $n$ number of adult mice and several ages should be considered when testing adult blood glucose regulation in PDX1-Cre/catenin lox/lox animals. Consistent with our results, the inactivation of LRP5 gene, coding a coreceptor of frizzled, results in impaired glucose-induced insulin secretion and glucose intolerance in adults [19]. Moreover, when the $\beta$-catenin protein is stabilised in pancreatic beta cells, the adult cells expand, plasma insulin is multiplied by 3 and blood glucose is significantly lower than in normal mice [16]. In the same way, reduced expression of the TCF7L2 gene (TCF4, coding a transcription factor regulated by $\beta$-catenin) in rodent beta cells impairs glucose-induced insulin secretion [40]. The defects observed in insulin secretion when TCF7L2 is downregulated do not originate from impaired insulin production or from altered expression of Glut2 (also known as Slc2a2) or glucokinase genes [21]. The expression of several genes involved in glucose response and insulin release also does not seem to be affected in the mutant mice studied here (Electronic supplementary material [ESM] Figs 1 and 2). Furthermore, the glucose intolerance observed in the $\mathrm{Catnb}^{\text {lox/lox }} / \mathrm{RIP}-\mathrm{Cre} \mathrm{e}^{+}$mice probably reflects defective glucose sensing and might be the outcome of exposure to low blood glucose levels at birth. Indeed, the prevalence of metabolic syndrome in adult humans is related to adverse events occurring in early life [41]. It would be interesting to determine whether lack of $\beta$-catenin in adults increases the risk of developing diabetes in a susceptible background.

The adult mice of the RIP-Cre strain in the C57B16/J genetic background display comparable metabolic defects [42] to those of the adult animals discussed here; the authors did not report any phenotype in the RIP-Cre ${ }^{+}$ newborns, which were obviously viable. However, considering the experimental design of the control groups and the severity of the phenotype observed here, we conclude that lack of $\beta$-catenin, but not the presence of the CRE gene, induces the abnormal glucose clearance and insulin release observed in adult Catnb ${ }^{\text {lox/lox }} / \mathrm{RIP}-\mathrm{Cre}^{+}$mice.
A characteristic of RIP-Cre transgenic mice is that the RIP promoter is also active in the hypothalamus [32] and in the pituitary [43], both being important for glucose homeostasis [44]. The mortality rate observed in the $\mathrm{Catnb}^{\text {lox/lox}} / \mathrm{RIP}-\mathrm{Cre}^{+}$pups may be enhanced by $\beta$ catenin deletion in these tissues. It would be of interest to check the function of the hypothalamus-pituitary axis of the mutant mice. Alternatively, targeted deletion of $\beta$ catenin in the hypothalamus or in the pituitary would be valuable models to help understand $\beta$-catenin functions in glucose homeostasis.

Acknowledgements We would like to thank D. Dietz (TSRI, La Jolla, CA, USA) for excellent technical assistance. We are grateful to the Sarvetnick's lab members for critical reading of the manuscript. We are also grateful to C. Wood (TSRI, La Jolla, CA, USA) for her administrative support, C. Lanigan (TSRI, La Jolla, CA, USA) for her help in statistical analyses, W. Kiosses (TSRI, La Jolla, CA, USA) for his advice on confocal microscopy and K. Rouault (INSERM U876, Bordeaux, France) for his expertise in Q-PCR. This work was supported by NIH grant DK060746 and by the Comité Départemental de Dordogne de la Ligue Régionale contre le Cancer AquitaineCharente. S. A. Dabernat was supported by the ACSBI ACS/05/015 fellowship of the International Union Against Cancer.

Duality of interest The authors declare that there is no duality of interest associated with this manuscript.

\section{References}

1. Nieset JE, Redfield AR, Jin F, Knudsen KA, Johnson KR, Wheelock MJ (1997) Characterization of the interactions of alphacatenin with alpha-actinin and beta-catenin/plakoglobin. J Cell Sci 110:1013-1022

2. Aberle H, Bauer A, Stappert J, Kispert A, Kemler R (1997) Betacatenin is a target for the ubiquitin-proteasome pathway. EMBO J 16:3797-3804

3. Nelson WJ, Nusse R (2004) Convergence of Wnt, beta-catenin, and cadherin pathways. Science (New York, NY) 303:1483-1487

4. Fear MW, Kelsell DP, Spurr NK, Barnes MR (2000) Wnt-16a, a novel Wnt-16 isoform, which shows differential expression in adult human tissues. Biochem Biophys Res Commun 278:814820

5. Heller RS, Dichmann DS, Jensen J et al (2002) Expression patterns of Wnts, Frizzleds, sFRPs, and misexpression in transgenic mice suggesting a role for Wnts in pancreas and foregut pattern formation. Dev Dyn 225:260-270

6. Heller RS, Klein T, Ling Z et al (2003) Expression of Wnt, Frizzled, sFRP, and DKK genes in adult human pancreas. Gene Expr 11:141-147

7. Hu E, Zhu Y, Fredrickson T et al (1998) Tissue restricted expression of two human Frzbs in preadipocytes and pancreas. Biochem Biophys Res Commun 247:287-293

8. Sagara N, Toda G, Hirai M, Terada M, Katoh M (1998) Molecular cloning, differential expression, and chromosomal localization of human frizzled-1, frizzled-2, and frizzled-7. Biochem Biophys Res Commun 252:117-122

9. Papadopoulou S, Edlund H (2005) Attenuated Wnt signaling perturbs pancreatic growth but not pancreatic function. Diabetes 54:2844-2851 
10. Huelsken J, Vogel R, Brinkmann V, Erdmann B, Birchmeier C, Birchmeier W (2000) Requirement for beta-catenin in anteriorposterior axis formation in mice. J Cell Biol 148:567-578

11. Dessimoz J, Bonnard C, Huelsken J, Grapin-Botton A (2005) Pancreas-specific deletion of beta-catenin reveals Wnt-dependent and Wnt-independent functions during development. Curr Biol 15:1677-1683

12. Murtaugh LC, Law AC, Dor Y, Melton DA (2005) Beta-catenin is essential for pancreatic acinar but not islet development. Development 132:4663-4674

13. Wells JM, Esni F, Boivin GP et al (2007) Wnt/beta-catenin signaling is required for development of the exocrine pancreas. BMC Dev Biol 7:4

14. Heiser PW, Lau J, Taketo MM, Herrera PL, Hebrok M (2006) Stabilization of $\beta$-catenin impacts pancreas growth. Development 133:2023-2032

15. Strom A, Bonal C, Ashery-Padan R et al (2007) Unique mechanisms of growth regulation and tumor suppression upon Apc inactivation in the pancreas. Development 134:2719-2725

16. Rulifson IC, Karnik SK, Heiser PW et al (2007) Wnt signaling regulates pancreatic beta cell proliferation. Proc Natl Acad Sci USA 104:6247-6252

17. Heiser PW, Cano DA, Landsman L et al (2008) Stabilization of beta-catenin induces pancreas tumor formation. Gastroenterology 135:1288-1300

18. Murtaugh LC (2008) The what, where, when and how of Wnt/ beta-catenin signaling in pancreas development. Organogenesis 4:81-86

19. Fujino T, Asaba H, Kang MJ et al (2003) Low-density lipoprotein receptor-related protein 5 (LRP5) is essential for normal cholesterol metabolism and glucose-induced insulin secretion. Proc Natl Acad Sci USA 100:229-234

20. Lyssenko V, Jonsson A, Almgren P et al (2008) Clinical risk factors, DNA variants, and the development of type 2 diabetes. $\mathrm{N}$ Engl J Med 359:2220-2232

21. da Silva Xavier G, Loder MK, McDonald A et al (2009) TCF7L2 regulates late events in insulin secretion from pancreatic islet $\beta$ cells. Diabetes 58:894-905

22. Brault V, Moore R, Kutsch S et al (2001) Inactivation of the betacatenin gene by Wnt1-Cre-mediated deletion results in dramatic brain malformation and failure of craniofacial development. Development 128:1253-1264

23. Postic C, Shiota M, Niswender KD et al (1999) Dual roles for glucokinase in glucose homeostasis as determined by liver and pancreatic beta cell-specific gene knock-outs using Cre recombinase. J Biol Chem 274:305-315

24. Gorogawa S, Fujitani Y, Kaneto H et al (2004) Insulin secretory defects and impaired islet architecture in pancreatic beta-cellspecific STAT3 knockout mice. Biochem Biophys Res Commun 319:1159-1170

25. Pende M, Kozma SC, Jaquet M et al (2000) Hypoinsulinaemia, glucose intolerance and diminished beta-cell size in S6K1deficient mice. Nature 408:994-997

26. Hole RL, Pian-Smith MC, Sharp GW (1988) Development of the biphasic response to glucose in fetal and neonatal rat pancreas. Am J Physiol 254:E167-E174

27. Roccisana J, Reddy V, Vasavada RC, Gonzalez-Pertusa JA, Magnuson MA, Garcia-Ocana A (2005) Targeted inactivation of hepatocyte growth factor receptor c-met in beta-cells leads to defective insulin secretion and GLUT-2 downregulation without alteration of beta-cell mass. Diabetes 54:2090-2102

28. Rooman I, Lardon J, Bouwens L (2002) Gastrin stimulates betacell neogenesis and increases islet mass from transdifferentiated but not from normal exocrine pancreas tissue. Diabetes 51:686690

29. Bernal-Mizrachi E, Wen W, Stahlhut S, Welling CM, Permutt MA (2001) Islet beta cell expression of constitutively active Akt1/PKB alpha induces striking hypertrophy, hyperplasia, and hyperinsulinemia. J Clin Invest 108:1631-1638

30. Gannon M, Shiota C, Postic C, Wright CV, Magnuson M (2000) Analysis of the Cre-mediated recombination driven by rat insulin promoter in embryonic and adult mouse pancreas. Genesis 26:139-142

31. Gu G, Dubauskaite J, Melton DA (2002) Direct evidence for the pancreatic lineage: NGN3+ cells are islet progenitors and are distinct from duct progenitors. Development 129:2447-2457

32. Gannon M, Herrera PL, Wright CV (2000) Mosaic Cre-mediated recombination in pancreas using the pdx-1 enhancer/promoter. Genesis 26:143-144

33. Dai C, Huh CG, Thorgeirsson SS, Liu Y (2005) Beta-cell-specific ablation of the hepatocyte growth factor receptor results in reduced islet size, impaired insulin secretion, and glucose intolerance. Am J Pathol 167:429-436

34. Sund NJ, Vatamaniuk MZ, Casey M et al (2001) Tissue-specific deletion of Foxa2 in pancreatic beta cells results in hyperinsulinemic hypoglycemia. Genes Dev 15:1706-1715

35. Hahn JY, Cho HJ, Bae JW et al (2006) Beta-catenin overexpression reduces myocardial infarct size through differential effects on cardiomyocytes and cardiac fibroblasts. J Biol Chem 281:30979-30989

36. Zelarayan LC, Noack C, Sekkali B et al (2008) Beta-catenin downregulation attenuates ischemic cardiac remodeling through enhanced resident precursor cell differentiation. Proc Natl Acad Sci USA 105:19762-19767

37. Bogdani M, Suenens K, Bock T, Pipeleers-Marichal M, In't Veld P, Pipeleers D (2005) Growth and functional maturation of betacells in implants of endocrine cells purified from prenatal porcine pancreas. Diabetes 54:3387-3394

38. Inoki K, Ouyang H, Zhu T et al (2006) TSC2 integrates Wnt and energy signals via a coordinated phosphorylation by AMPK and GSK3 to regulate cell growth. Cell 126:955-968

39. Slavik MA, Allen-Hoffmann BL, Liu BY, Alexander CM (2007) Wnt signaling induces differentiation of progenitor cells in organotypic keratinocyte cultures. BMC Dev Biol 7:9

40. Loder MK, da Silva Xavier G, McDonald A, Rutter GA (2008) TCF7L2 controls insulin gene expression and insulin secretion in mature pancreatic beta-cells. Biochem Soc Trans 36:357-359

41. Cameron N, Demerath EW (2002) Critical periods in human growth and their relationship to diseases of aging. Am J Phys Anthropol Suppl 35:159-184

42. Lee JY, Ristow M, Lin X, White MF, Magnuson MA, Hennighausen L (2006) RIP-Cre revisited, evidence for impairments of pancreatic beta-cell function. J Biol Chem 281:2649-2653

43. Martin J, Hunt SL, Dubus P et al (2003) Genetic rescue of Cdk4 null mice restores pancreatic beta-cell proliferation but not homeostatic cell number. Oncogene 22:5261-5269

44. Prodi E, Obici S (2006) Minireview: the brain as a molecular target for diabetic therapy. Endocrinology 147:2664-2669 